\title{
A model of political leadership characteristics leading to country development
}

\author{
Sathit Pitutecha \\ Thanin Silpcharu
}

Faculty of Business Administration

King Mongkut's University of Technology North Bangkok, Thailand

\section{Keywords}

Characteristics model, political leadership, structure equation modeling

\begin{abstract}
At present, overall dimensions of leadership quality in Thailand tend to decrease dramatically. When considering political context in Thailand, it was found that Thailand is facing crisis in political leadership. This study aimed to investigate political leadership characteristics leading to country development and to develop a structural equation model. The researchers collected qualitative data by interviewing experts in the field and collecting quantitative data by interviewing 500 political leaders at the local and national levels. The data analysis yielded the political leadership model consisted of 5 aspects; namely, Interpersonal Building related to thinking and implementing projects beneficial to society at large; Individualized Consideration in relation to utilizing personnel according to their ability; Intelligence concerning having ability to analyze problems and having courage to make right decisions in every situation; Integrity involving loving and being faithful to the nation, religion, the king and the organization; Interpersonal Attribution including persistence, devotion and sacrifice. After testing the hypotheses, it was found that political leaders at the national and local levels differently emphasized overall leadership characteristics for country development. The analysis of the structural equation model developed by the researcher revealed that the model passed the assessment criteria and accorded with the empirical data with Chi-square value of 0.722 , relative Chi-square value of 0.948 , IOC value of 0.961, and RMSEA of 0.000. The hypotheses testing of the model showed that Intelligence had direct effect on Interpersonal Building, while Integrity had direct effect on Intelligence and Interpersonal Building. However, Interpersonal Building had direct effect on Individualized Consideration and Interpersonal Attribution also had direct effect on Integrity. The statistical significance level of this study was set at 0.05.
\end{abstract}

Corresponding author: Sathit Pitutecha

Email addresses for the corresponding author: sunee.w@fba.kmutnb.ac.th

First submission received: $3^{\text {rd }}$ April 2018

Revised submission received: $5^{\text {th }}$ June 2018

Accepted: $17^{\text {th }}$ August 2018

\section{Introduction}

Leadership has been a hot and interesting topic during the first decade of the $21^{\text {st }}$ century due to the emergence of several indicative factors. It is predicted that this trend will affect leadership and the realm of political administration in the future. Leaders will have influence on the others, causing leadership and followership. Leaders have a target to motivate and push followers to work and achieve the organization goals. Decisions made by leaders specifically political leaders cannot be considered as just their own, but decisions on behalf of the people from the whole country. Decisions made by the leaders of superpower countries would inevitably affect economics, politics, society and security of other countries.

Bureaucracy has been established in Thailand for government and public administration, having specified laws and rules, and having government officials to perform the duties according to the laws. The government officials do the planning and budgeting in order to provide services to people according to the mandates and power specified by laws. According to the democratic regime, the government and public administration are headed by the Prime Minister and the Cabinet as well as the Presidents of the National Legislative Assembly and the Senate (Office of the Council of State, 2007). Leaders of political parties can play their political roles. 
India Infoline News Service (2014) did a survey on leadership indicator as shown in figure 1. The survey revealed that leadership indicators of India, Mexico, the Philippines and South Africa were at a high level, while leadership indicators of Australia, Taiwan and Thailand were at a medium level. However, it was found that leadership quality in Australia from 2011-2014 had been improved, while Taiwan remained the same. It was also noticed that, when compared with Australia and Taiwan, leadership quality in Thailand was decreased.

\begin{tabular}{|l|l|}
\hline Countries & Leadership Quality \\
\hline Australia & India \\
\hline Mexico & \\
\hline The Philippines & \\
\hline South Africa & \\
\hline Taiwan &
\end{tabular}

Figure 1: Leadership quality indicators 2014

Notes:

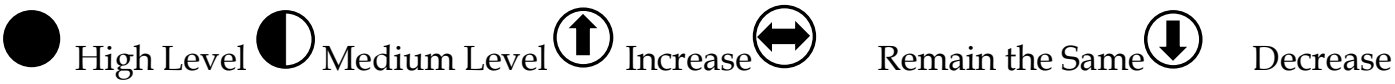

As leadership in Thailand as a whole tends to be declined, it indicates that Thailand is facing leadership crisis. Furthermore, when looking back to political context in the past, it is confirmed that Thailand is really facing political leadership crisis

\section{Literature Review}

The words "Political leaders" originated from Greek language "Polis." It refers to those who are involved with having influence on public policy and decision-making, and those who make decisions in the government, as well as those who work in that capacity. They may come from election, succession, coup d'état, appointment, or other means. Politics is not limited to administration through public positions only, but political positions may be in any corporations. In other words, political leaders are those holding outstanding positions involved with using power and authority in government structure and being persons who have power and influence in real political decision-making process. Political leaders can be divided into 2 levels: (1) National level: the prime minister, ministers, members of parliament, senators and political party executives belong to this group, and (2) Local level: Political leaders in this group include local administration, city mayors, local councilors, city councilors, subdistrict headman and village headman all of whom come from the election. Political leaders are politicians or those who perform political works which are important to political and public administration development because politicians gain trust from people to work on their behalf by giving their power to the politicians to govern the country.

Several studies (Chrastka, 2017; Hill \& Jochim, 2017; Kgatle, 2018; Randolph \& Sanders, 2011; Sunindijo, 2012) had been conducted to explore the key characteristics of political leadership. Randolph and Sanders (2011) examined thoughts of Mrs. Ethel Thompson Overby, who was the educational leadership of the first African American female principal in Richmond, Virginia. Within the severe contexts of school, Overby utilized critical and cultural pedagogy to alter her students' life choices by first educating them to the political, social, and structural inequalities of their society, of which school is a part. 
Second, Overby provided the students with opportunities to foster their own access and change in the system of education through collective action. She redirected the impact of racist and uryust educational policy through community engagement. Finally, Overby garnered educational resources through the curriculum to overcome structural impediments to students' academic engagement.

Chrastka (2017) stated about engaging political literacy as part of leadership development. He pointed out that one critical literacy that often lacks a coherent or intentional approach in library programs is political literacy. He also argued for the extension of literacy trainings for youth to teaching them about politics, policy, and political actions. Such programs should focus on helping youth attain the skills they need to become self-directedlearners, discoverers, and doers. He mentioned two factors motivating any person to be civically engaged: level of trust of involvement in government, and credibity in voting. Chrastka pointed out one challenge for youth advocates is the use of technology and app/web/social-based actions to help promote deliberative, long-term engagement from youth.

Sunindijo (2012) conducted a survey research with 273 respondents and found that self-awareness is the prerequisite that initiates the inter-relationship between emotional intelligence, political skill, and transformational leadership. Sunindijo concluded with the model for developing project personnel. The base skills for project personnel were selfawareness, apparent sincerity, and self-management. The next skill set was the ability to observe and understand people consisting of social awareness and social astuteness skills. Thereafter, project personnel could focus on their social skills including networking ability, interpersonal influence, and relationship management. At final, project personnel would improve their contribution in the achievement of project objectives and become transformational leaders.

Based on Neustadt's book on "Presidential Power is the Power to Persuade", Hill and Jochim (2017) proposed the persuation conception to achieve the task as a Chief state school for linking state and school improvement. These key characteristics are raised: Bargaining, Professional reputation, Building coalitions, Creating allies, Building and dmonstrating skill (i.e. Controlling subordinates, Controlling the chief's own time, and Using personal prestige) and Making decisions to maximize power.

Kgatle (2018) discussed about the current political leadership in South Africa. South African call for a unique approach to public governance, management and leadership. They call for a different system that can turn governance around to make it more trustworthy and accountable. Kgatle stated that, in response to these aspects, the article demonstrated that servant leadership is an urgent style for the current state of political leadership in South Africa. At final, Kgatle proposed four key principles of servant leadership including servant leadership is service, humility, and stewardship, and servant leadership is to lead by example.

Casper (2002) stated that political leaders at the age of "only the fittest survive" or the age that the strongest politicians survive like those at present, must have 3 qualifications of good politicians as follows: 2.1 Good political leaders must maintain honor and honesty because, in the present era, people are being-themselves at a high level and are able to lead themselves at different degrees. Thus, political leaders must develop themselves to be "leaders of the leaders".

2.2 Political leaders must have visions. They must be able to create visions that can come true, be trustworthy and meet the organization potentials and situations. Moreover, those visions must be challenging and attractive to people in such a way that they want to make them come true successfully, leading to higher work standards. Organization itself must impose long-term vision, easy to understand, and covering broad perspectives. Good visions created by leaders must include consideration of using organizational resources, especially human resources at the optimal benefits. To do so, leaders must have a role in stimulating employees to devote themselves to their work at their full potentials.

2.3 Good political leaders must have "the heart of child". By having "the heart of child," it means optimism, thinking positively, making decision based on pure conscious without thinking of their own interests. Besides, leaders must be curious, and enthusiastic to seek new knowledge to fulfill themselves, learn by mistakes, and give a chance for new experience by being persistent to solve problems not by finding the wrongdoers because that will unexpectedly reduce morale of the employees.

Based upon the aforementioned literature, this study conceptualizes the political leadership characteristic for country development in the age of globalization as consisting of five important characteristics, namely, 
Interpersonal Building (IB), Individualized Consideration (IC), Intelligence (IG), Integrity (IR), Interpersonal Attribution (IA).

\section{Hypotheses}

Based upon the literature about the political leadership characteristic, the researcher set the hypotheses about the relationship between five factors of political leaders' characteristics leading to country development: IG, IB, IR, IC, and IA, as follows.

$\mathrm{H}_{1}$ : Intelligence (IG) factor had direct effect on Interpersonal Building (IB) factor.

$\mathrm{H}_{2}$ : Integrity (IR) factor had direct effect on Intelligence (IG) factor.

$\mathrm{H}_{3}$ : $\quad$ Integrity (IR) factor had direct effect on Interpersonal Building (IB) factor.

$\mathrm{H}_{4}$ : Interpersonal Building (IB) factor had direct effect on Individualized Consideration (IC) factor.

$\mathrm{H}_{5}$ : Interpersonal Attribution (IA) factor had direct effect on Integrity (IR) factor.

\section{Research Methods}

This study was an inductive research employing mixed-research methods. In qualitative research method, the researchers conducted in-depth interview with nine experts and conducted focus group discussion with seven experts. The panel of experts was a person who was well-accepted in the field of political leadership in Thailand.

In quantitative research method, the sample was politicians at national and local levels in Thailand. The sample size of this research was set for 500 samples according to Comrey and Lee's Criteria (Lawrence, Glenn \& Guarino, 2017). Samples were randomly selected using multi-stage random sampling technique. The sample was asked to respond to the 125-item questionnaire. The questionnaire was checklist and Likert's 5-point rating scale questionnaires (David \& Sutton, 2011, p. 259). The analysis of index of congruence (IOC) of items was ranged from 0.60 to 1.00 , which was acceptable. The reliability of the questionnaire was shown by Cronbach's alpha coefficient at 0.92 . The discrimination of the questionnaire was calculated with corrected item-total correlation and the result was ranged from 0.33 to 1.47 (Babbie, 2015, pp. 211-217). This showed that the questionnaire used in this study is valid and reliable.

To analyze data, the researchers used both descriptive and inferential statistics. The SPSS was used to analyze descriptive statistics and the AMOS was used to analyze inferential statistics as multivariate statistical analysis and for development of structural equations modeling (SEM). Four criteria for evaluating the data-model fit were (Arbuckle, 2011, pp. 555-556): Chi-square probability level $>0.05$, relative Chi-square $<2$, goodness of fit index $>0.90$, and root mean square error of approximation $<0.08$.

\section{Research Results}

5.1 General characteristics of organizations and politicians' political operation responded by participants and calculated in percentage were as follows: Before holding political positions, the participants used to be businessmen, administrators, or owned some business $(42.00 \%)$. The main reason for people to choose each politician was that they themselves considered the politicians $(44.20 \%)$. The main revenue of politicians' political organization was the budget allocated by the government $(58.40 \%)$. Conflicts within organizations were major problems or obstacles that weakened political organizations $(29.20 \%)$. In general, politicians developed their political skills by meeting and exchanging ideas, attending seminars, participating in training and meeting with experts in specific fields $(51.40 \%)$. The ways to improve political organizations were promoting good image, building trust and faith to people inside and outside organizations (37.20\%). Collaboration and unity were important way to achieve the goals $(64.60 \%)$. The most satisfying political works were those that met their knowledge, ability and aptitude $(38.20 \%)$. The important reason for being politicians was desired to participate in solving the country's problems $(47.60 \%)$. The most dissenting political situation was corruption $(47.80 \%)$. The approach most used for election campaign was continuous participation in social activities so as to be accepted by communities (54.60\%).

5.2 The investigation revealed that political leaders' important characteristics in relation to interpersonal building were: thinking and implementing projects useful for society at large $(\overline{\mathrm{X}}=4.38)$, 
helping people promptly during disasters $(\overline{\mathrm{X}}=4.37)$, and continuously and consistently participating in social and cultural activities $(\bar{X}=4.20)$ respectively.

Regarding individualized consideration, the item rated the highest was putting the man in the right job $(\bar{X}=4.36)$, followed by creating consciousness of dignity to love themselves and their organizations $(\bar{X}=4.28)$, and appropriately assigning and decentralizing authority to co-workers $(\bar{X}=$ 4.28) respectively.

With respect to intelligence, political leaders with ability to analyze problems and being brave to make decision right in time for every situation was rated the highest $(\bar{X}=4.38)$, followed by correctly prioritizing the missions; i.e. what should be done first, next, and last $(\bar{X}=4.33)$, and promptly solving immediate problems $(\bar{X}=4.33)$ respectively.

As for integrity, the item ranked the highest was love and faithful to nation, religion, the king and the organization $(\bar{X}=4.64)$, followed by not supporting every form of corruption $(\bar{X}=4.58)$, and announcing the standing point, emphasizing morality and honesty $(\bar{X}=4.56)$ respectively.

In relation to interpersonal attribution, the items rated the highest was being determined, devoted, and sacrificing $(\bar{X}=4.47)$, having democratic mind $(\bar{X}=4.46)$, and being down to earth and friendly with people of every social status $(\overline{\mathrm{X}}=4.45)$ respectively.

5.3 The comparison of characteristics of political leaders as classified by levels of politicians was made by using t-test to examine the difference of mean between 2 independent groups of population. It was found that politicians at the national level paid more attention to political leaders' characteristics than those at the local level. The finding was statistically significant at a level of .05.

5.4 The evaluation of congruence of the developed model yielded the Relative Chi-square value of 2.787 and root mean square error of approximation of 0.060 both of which passed the congruence criteria and were in line with the empirical data. However, its Chi-square probability level and goodness of fit index value did not yet pass the assessment criteria.

The model was, therefore, modified, taking into consideration Modification Indices value as recommended by Arbuckle (2011, pp. 107-109). After the modification, it was found that the values of Chi-square probability level, relative Chi-square, goodness of fit index, and root mean square error of approximation were. $722,948, .961$, and.000 respectively, all of which passed the criteria used to assess the model as shown in Figure 2 below:

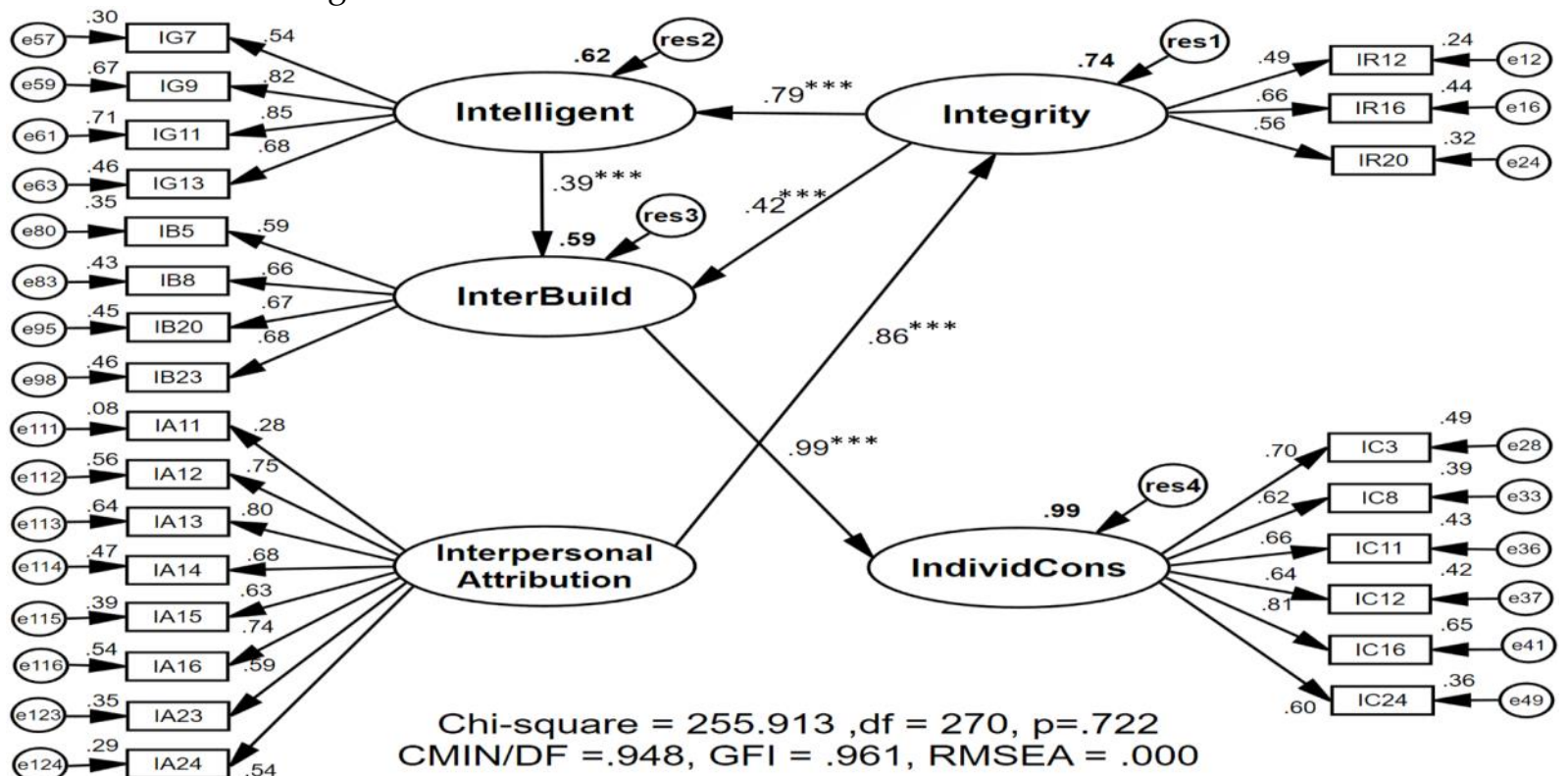

Figure 2: The political leadership characteristics model for country development, after being improved 
From Figure 2, meaning of the variables of the political leadership characteristics model for country development was shown in Table 1.

Table 1: Meaning of variables of the political leadership characteristics model for country development

\begin{tabular}{|c|c|}
\hline Variable & Meaning \\
\hline IB5 & $\begin{array}{l}\text { Creating Line or Facebook group to exchange information and communicate among the } \\
\text { group. }\end{array}$ \\
\hline IB8 & $\begin{array}{l}\text { Participating in working groups of public or private organizations that work for benefits of } \\
\text { the society. }\end{array}$ \\
\hline IB20 & Coordinating ideas and mutual benefits of each party appropriately. \\
\hline IB23 & Sharing knowledge and experience with people of all classes when opportunities arise. \\
\hline IC3 & $\begin{array}{l}\text { Creating good organizational culture to serve as direction and framework for employees to } \\
\text { follow while working. }\end{array}$ \\
\hline IC8 & Assigning works and decentralizing authority to co-workers appropriately. \\
\hline IC11 & Giving support on instruments and equipment sufficient for team's needs. \\
\hline IC12 & Emphasizing joint responsibility for any results occurred. \\
\hline IC16 & $\begin{array}{l}\text { Seriously and continuously monitoring and evaluating work performance of employees } \\
\text { being assigned. }\end{array}$ \\
\hline IC24 & Making a charter for working as a team that shows each person's responsibility. \\
\hline IG7 & Practicing thinking, synthesizing and analyzing to gain wisdom themselves. \\
\hline IG9 & Making decision based on thoroughly synthesized data. \\
\hline IG11 & Being able to see the connection of problems and being able to solve them appropriately. \\
\hline IG13 & Being able to clarify situations logically and reasonably. \\
\hline IR12 & Being determined to work for success, using morality as navigation tool. \\
\hline IR16 & $\begin{array}{l}\text { Respecting people because of their virtues and honesty, not because of social or financial } \\
\text { status. }\end{array}$ \\
\hline IR20 & $\begin{array}{l}\text { Disclosing corruption information to the public in order to use social penalties against } \\
\text { offenders. }\end{array}$ \\
\hline IA11 & Being oneself, not under any people's persuasion. \\
\hline IA12 & Being eager to seek new knowledge for self-development. \\
\hline IA13 & Listening to other people's problems with understanding. \\
\hline IA14 & Having democratic mind. \\
\hline IA15 & Being brave to think, take a risk, and make decisions. \\
\hline IA16 & Learning to forgive and to offer opportunities to others. \\
\hline IA23 & Being enthusiastic to work. \\
\hline IA24 & Possessing acceptable education qualifications. \\
\hline
\end{tabular}

After modified the political leadership characteristics model for country development, the model was tested again, and the result was shown in Table 2.

Table 2: Statistical values obtained after the model was modified.

\begin{tabular}{|l|l|l|l|l|l|}
\hline Variables & $\begin{array}{l}\text { Standardized } \\
\text { Estimates }\end{array}$ & $\mathrm{R}^{2}$ & Variance & C.R. & $\mathrm{p}$ \\
\hline Intelligence & & & & & \\
\hline $\begin{array}{c}\text { Interpersonal Building } \\
\text { Integrity }\end{array}$ & 0.39 & 0.59 & 0.13 & 4.38 & $* * *$ \\
\hline $\begin{array}{c}\text { Intelligence } \\
\text { Interpersonal Building }\end{array}$ & 0.79 & 0.62 & 0.08 & 8.00 & $* * *$ \\
\hline Interpersonal Building & 0.42 & 0.59 & 0.13 & 4.47 & $* * *$ \\
\hline $\begin{array}{c}\text { Individualized Consideration } \\
\text { Interpersonal Attribution }\end{array}$ & 0.99 & 0.99 & 0.01 & 12.03 & $* * *$ \\
\hline Integrity & 0.86 & & & & \\
\hline
\end{tabular}

Table 2 showed that the Intelligence factor had direct effect on Interpersonal Building at 0.001 level of statistical significance and with factor loading value of 0.39 . The Integrity factor had direct effect on Intelligence and Interpersonal Building at 0.001 level of statistical significance and with factor loading 
value of 0.79 and 0.42 , respectively. The Interpersonal Building factor had direct effect on Individualized Consideration at 0.001 level of statistical significance and with factor loading value of 0.99 . In addition, the Interpersonal Attribution factor had direct effect on Integrity at 0.001 level of statistical significance and with factor loading value of 0.86 .

The findings support the relationship between key characteristics of the proposed political leadership model including Interpersonal Building, Individualized Consideration, Intelligence, Integrity, Interpersonal Attribution. The directions of relationship are also presented. This shows that the relationship of those key characteristics is quite complex.

\section{Discussion}

\section{The findings lead to this discussion}

6.1 It was found in this study that integrity was the most important characteristics of political leaders. This finding was in line with Total Ethical Theory which stated that the role of political leaders with respect to ethics could reduce abnormal working behaviors. Unethical behaviors of the leaders would not only be dangerous to organizations but also to the country as a whole (Chiang and Birtch, 2013).

6.2 This study revealed that intelligence had direct effect on interpersonal building. Thus, political leaders who possessed qualifications and intelligence would be able to drive thoughts, decision-making as well as building good relationships with people around them. This finding was in line with research work of Meng et al (2015) who studied relationships between top political leaders and sustainability of basic infra-structure development in China. The purpose of his study was to survey relationships between ability of being leaders and abilities of using intelligence, management, emotion and socialization. He found that intelligent ability had effect on emotion and network building.

6.3 This study indicated that integrity had direct effect on intelligence. As political leaders lived their lives on the ground of being moral, ethical and honest in performing their duties, keeping their promise with people, these would reflect their behaviors while performing duties as well as personal behaviors. Integrity would help leaders to be emotionally stable, and mindful, to ponder the action, to think carefully, all of which could lead to working with intelligence. These were strong indicators for political leaders to be acceptable and respectful, to be mentioned and trusted by the people. This finding was in line with the research work of Zbierowski and Gora (2014).

6.4 It was found in this study that integrity had direct effect on Interpersonal Building. Leaders who had integrity would help organizations maintain interpersonal relationships with people within organizations and society at large. This finding was in line with Luu's research work (2013) who studied whether social responsibility had high influence on employee's work behaviors, team working process and competition ability. Luu believed that working with integrity had some relationship with stakeholders' social expectation. Particularly it would best help maintain good interpersonal relationship between employees within organizations and the outsiders. This finding was also in line with Ghosh's research work (2015) that examined leaders with good heart, sacrificing to work for non-profit organizations. It was found that leaders with integrity would have positive effect on interpersonal building among personnel in the organization.

6.5 This study revealed that interpersonal building had direct effect on individualized consideration. Interpersonal building factor would directly and indirectly occur between a person and people. This relationship could explain behaviors of people around that network. Interpersonal Building would help people in organizations feel friendly and trustworthy, give opportunities to listen to ideas and to exchange information among them without using only authority. Teamwork or personnel in organizations did not, therefore, feel that they worked just for the sake of work, having no interpersonal relationships with their leaders, lacking commitment with organizations and leaders. Leaders had to stimulate everyone to work as being a part of the organizations and to love the organizations more than the benefits from work (Luu, 2013).

This finding was also in line with Brouer and colleague's research work (2016) that studied political skill dimension and transformation leadership in China and found that leaders with political ability would be able to build networks, leading to acceptance. When leaders were well accepted, they would be able to persuade their followers to believe in their visions, and followers' cooperation and support would be an ultimate gain. 
6.6 This study showed that interpersonal attribution had direct effect on integrity. Such finding was in accordance with Tabatabei and Zavareh's research work (2014) that studied the results of being spiritual, moral, and ethical leaders according to employees' views. They claimed that spiritual leaders could be measured by their clever ideas, outstanding consciousness, focusing on development. While the moral and ethical ones could be measured by their being fair, responsible, honest, and accuracy-oriented, as well as their respect to the others. It was also found that being spiritual would make leaders to be moral and ethical too. Being moral and ethical was a characteristic of leaders who respected other people's right, accepted other people's value, were moral, fair, and honest to every people, and focused on doing the right things. Such leaders already possessed spirit of being good people in them. Thus, spiritual leaders significantly had positive effect on moral and ethical leaders.

\section{Recommendations}

According to the result of this study, integrity was the most important characteristics that would lead to the country development. It should be possessed by political leaders both at national and local levels. As political leaders have to do administration job for the benefits of the public and the country, they must have integrity, honesty and be determined to sacrifice no matter how situations and time have been changed. The political leadership model found from this study expresses the initiative for country development. It is very important for the developing country as Thailand. The findings about political leadership model will be disseminated in several meetings and conferences in order to make the best possible contribution from this study. To be successful, political leaders are recommended to do as follows:

7.1 Political leaders should render knowledge to the people so that they can keep up with changes and political situations. Moreover, the political leaders should show them good and bad examples of politicians so that they will be able to choose the right political leaders for the benefits of the people in the long run.

7.2 Political leaders should have more restraint and morality than the others in terms of not following the current situation or doing something that might destroy the structural system and the country administration principles, just for the sake of overcoming the election.

7.3 Political leaders should stop and solve problems of the country or political organizations by using the given authority and making decisions according to the right principles and the rules of law even though they may lose power or own interest.

7.4 There are many research topics that can be raised from the political leadership model found in this study such as the verification of applicability of the model in the real educational contexts and finding the good example of schools with those characteristics of the political leadership model and study what effects occurred from the model.

\section{References}

Arbuckle, J. L. (2011). IBM SPSS Amos 20 User's Guide. NY: Amos Development Corporation.

$\mathrm{Au}, \mathrm{K} ., \mathrm{Chiang}$, Flora F. T., Birtch, Thomas A., \& Ding, Z. (2013). Understanding leading, leader-follower relations, and ethical leadership in organizations. Relationships in organizations: a work psychology perspective, 11, 239-267.

Brouer, R. L., Chiu, C., \& Wang, L. (2016). Political skill dimensions and transformational leadership in china. Journal of Managerial Psychology, 31(6), 1040-1056.

Casper, S. (2002). New Leaders for the Next Century. Productivity World.

Chrastka, J. (2017). Creating tomorrow's civic leaders by learning to be civically engaged today. Young Adult Library Services, 15(4), 13-16.

David, M. and Sutton, C. (2011). Social Research an Introduction. 2nd ed. London: Sage Publications.

Ghosh, K. (2015). Benevolent leadership in not-for-profit organizations. Leadership \& Organization Development Journal, 36(5), 592-611.

Hill, P., \& Jochim, A. (2017). The power of persuasion: A model for effective political leadership by state chiefs. Seattle, WA: Center on Reinventing Public Education (CRPE).

India Infoline News Service. (2015). Leadership quality and Leadership bench strength unchanged in India. [online] August 2014.

Kgatle, M. S. (2018). Servant leadership: An urgent style for the current political leadership in South Africa. Vwrbum et Ecclesia, 39(1), 1-9. 
Luu, T. T. (2013). Corporate social responsibility, upward influence behavior, team processes and competitive intelligence. Team Performance Management, 19(1), 6-33.

Meng, J., Xue, B., Liu, B., \& Fang, N. (2015). Relationships between top managers' leadership and infrastructure sustainability. Engineering, Construction and Architectural Management, 22(6), 692-714.

Office of the Council of State. (2007). Royal Thai Government Gazette. Bangkok: Constitution of the Kingdom of Thailand.

Randolph, A. W., \& Sanders, S. (2011). In search of excellence in education: The political, academic, and curricular leadership of Ethel T. Overby. Journal of School Leadership, 21, 521-547.

Sunindijo, R. Y. (2012). Integrating emotional intelligence, political skill, and transformational leadership in construction. Civic Engineering Dimension, 14(3), 182-189.

Tabatabei, S. A. N., \& Zavareh, F. B. (2014). Effect of Spiritual Intelligence, The Moral Leadership of the Employee's Perspective; (Case Study: Isfahan University Staff and Najaf Abad Azad University). Kuwait Chapter of the Arabian Journal of Business and Management Review, 4(1), 379-389.

Zbierowski, P., \& Góra, K. (2014). Positive leadership: Its nature, antecedents and consequences. Journal of Positive Management, 5(1), 85-99. 